\title{
ELABORASI DAN EKSPLORASI PEMAHAMAN FIKIH KONTEMPORER
}

\section{Muhtadin Dg. Mustafa}

STAIN Datokarama Palu, Jl. Diponegoro 23 Palu e-mail: muhtadin.dg.mustafa@gmail.com

\begin{abstract}
This article elaborates the probelms of undersatanding the material of Islamic learning popularly known as figh, which is regarded less dinamical and less responsive to the change of time. Therefore, fiqh is very important to discuss since nowadys it is faced with the methodology of its implementation, that its infiteness between legal dictum having been formulated by claasical Muslim scholars with condition and legal probelms of their own as well as justice sense of Muslim society where the law was implemented. Wthin this context, a methodology of implementing fiqh is crucial to study in accordance with the change of room and of time.

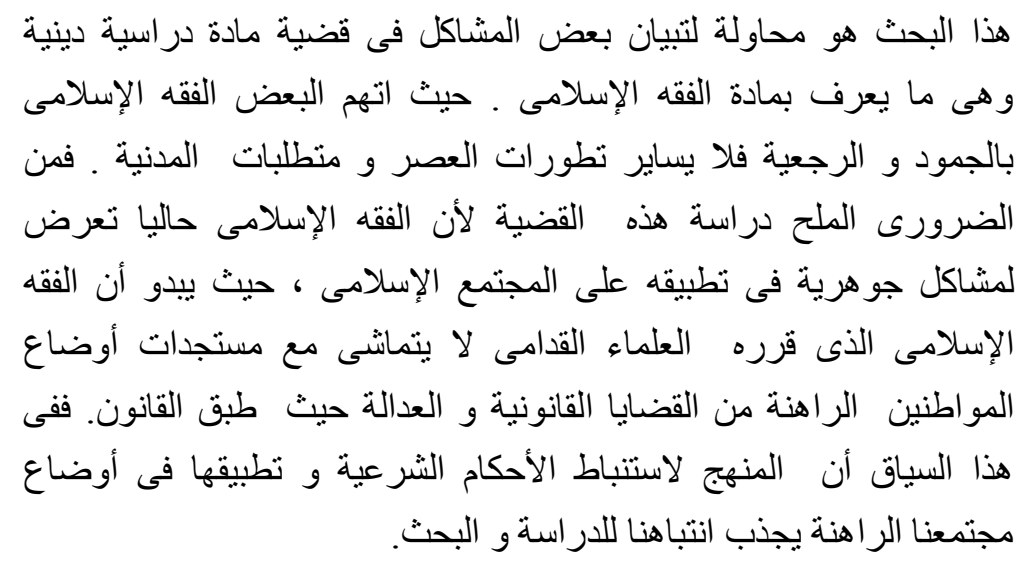

Kata Kunci: pemahaman fikih, hukum Islam, Alquran, sunah, ijtihad 


\section{PENDAHULUAN}

Islam sebagai sistem religi adalah paket tingkah laku untuk mencapai kebahagiaan di dunia dan di akhirat. Islam menjanjikan kehidupan yang mengandung materi dan spritual, serta merupakan konsepsi menyeluruh untuk suatu tingkah laku bagi insan kamil. Untuk itu diperlukan pemahaman fikih yang tidak saja melibatkan manusia sebagai pelaku utama dalam sistem hukum, tetapi beranjak dari Tuhan.

Dewasa ini meskipun penduduk Indonesia mayoritas beragama Islam, tetapi yang berlaku bukanlah hukum Islam. Posisi Hukum Islam hanyalah kelemahan manusia, maka setiap langkah manusia tidak boleh meninggalkan sebagai konsepsi hukum yang mempengaruhi keseluruhan sistem hukum di Indonesia yang secara multi kompleks diserap menjadi suatu sistem yang ideal untuk Indonesia. Dengan kata lain bahwa hukum Islam berfungsi sebagai penyaring produk-produk hukum Nasional yang akan diberlakukan bagi masyarakat Indonesia.

Hukum Islam (fikih) yang bersumber dari Alquran dan sunah nabi, dapat dipahami melalui proses penalaran atau ijtihad. Ijtihad, yang oleh sebagian ulama fikih dipahami sebagai kesungguhan dan pengarahan segala kemampuan pemikiran secara optimal untuk menemukan hukum-hukum syara' dan pengalamannya akan dapat menampakkan dan mengaktualkan petunjuk-petunjuk wahyu yang karenanya memungkinkan untuk diamalkan. Dengan ijtihad inilah sifat elastisitas dan akomodatif Hukum Islam (fikih) ditampakkan.

Dengan berlalunya waktu, perkembangan fikih yang dinamis dan kreatif pada masa awal kemudian menjelma ke dalam bentuk mazhabmazhab atas inisiatif beberapa ahli hukum terkenal. Sejak saat itu, para ulama-ulama fikih mulai berusaha menemukan kandungan syar'i melalui interpretasi guna merespons problema-problema yang muncul setelah nabi wafat. Bukan hanya sampai di situ, ketika wilayah kekuasaan Islam semakin luas, disusul dengan kemajuan peradaban pada masa Dinasti Abbasiyyah, ulama fikih semakin giat merumuskan pemikirannya sebagai langkah antisipasi terhadap hal-hal yang belum pernah ditetapkan hukumnya oleh generasi sebelumnya.

Usaha keras yang dilakukan oleh ulama fikih pada masa itu telah melahirkan diktum-diktum hukum (produk ijtihad) yang benar-benar aktual dan kondisional. Tradisi ijtihad yang demikian kuat melahirkan pemikiran-pemikiran yang cerdas, cemerlang dan responsif terhadap 
tantangan zamannya, telah menghantarkan umat Islam pada masa kemajuan Islam pertama (Tahun $700-1000$ M.) atau sekitar abad I sampai abad IV Hijriah (Nasution, 1985:12).

Walaupun demikian, seiring dengan berlalunya waktu, perkembangan hukum Islam (fikih) yang dinamis dan kreatif pada masa awal perkembangan Islam, berubah menjadi statis dan kurang apresiatif terhadap laju perkembangan masyarakat. Hal ini muncul di saat terjadinya kristalisasi mazhab-mazhab yang membuat hak untuk berijtihad mulai dibatasi dan pada gilirannya dinyatakan tertutup. Bahkan pada pertengahan abad ke-3 H/9 M, muncul gagasan bahwa hanya ulama-ulama besar masa lampaulah yang berhak melakukan ijtihad (Amal, 1989:35). Ini tentunya membuat tradisi kebebasan berfikir dan upaya untuk menemukan kandungan hukum syar' $i$ terhenti dan dapat berakibat buruk bagi perkembangan pemikiran hukum dalam Islam.

Kondisi ini telah membawa kepada suatu keadaan dimana fikih tidak lagi mampu merespons tuntutan perkembangan sosial. Produkproduk pemikiran (sebagai hasil ijtihad) tidak berkembang seiring dengan merebaknya doktrin "tertutupnya" pintu ijtihad. Meskipun hal ini dibantah oleh Muhammad Iqbal, sebagaimana dikutip Taufik Adnan Amal, mengatakan bahwa secara teoritis ijtihad memang tidak dinyatakan tertutup. Penutupan pintu ijtihad itu hanyalah fiksi semata yang sebagiannya disebabkan oleh kristalisasi pemikiran dalam hukum Islam, dan sebagiannya oleh kemalasan intelektual yang telah mengubah pemikir-pemikir besar menjadi berhala-berhala (Amal, 1989:35). Tradisi ijtihad berubah menjadi tradisi taklid (Ash-Shiddieqy, 1987:80), yang umumnya diartikan sebagai penerima secara mutlak terhadap doktrin-doktrin mazhab-mazhab dan otoritas pemikirannya.

Meskipun kondisi perkembangan hukum Islam sedemikian suram, terutama pasca menjalarnya doktrin tertutupnya pintu ijtihad, bukan berarti aktivitas ulama fikih telah berhenti sama sekali. Aktivitas para kadi (hakim) dan mufti misalnya, merupakan bentukbentuk upaya menumbuhkan dan merumuskan Hukum Islam. Kadi dalam hal ini menghasilkan yurisprudensi dan mufti menghasilkan fatwa.

Dengan demikian, produk pemikiran hukum Islam yang selama ini hanya fikih, telah berkembang ke pemikiran hukum yang lebih kondusif dengan lahirnya yurisprudensi dan fatwa. Namun demikian, 
ketiga produk pemikiran hukum Islam ini dianggap belum cukup untuk menjawab semua problema dan kebutuhan akan hukum di masyarakat, maka dibuatlah undang-undang sebagai hukum tertulis yang dapat mengikat suatu masyarakat yang sedang berkembang.

Di Indonesia yang mayoritas penduduknya beragama Islam juga sangat membutuhkan produk-produk hukum yang sejalan dengan tuntutan kebutuhan masyarakat. Oleh karena itu, keempat produk pemikiran hukum Islam di atas (fikih, fatwa, yurisprudensi dan undang-undang) berjalan secara sinergis sesuai dengan kebutuhan hukum masyarakat Islam di Indonesia. Akan tetapi, bila dicermati lebih jauh, produk-produk pemikiran hukum Islam ini seringkali tak menyentuh rasa keadilan masyarakat. Hal ini mungkin karena produkproduk hukum tersebut tidak dilandaskan pada sebuah konsepsi kebutuhan hukum kontemporer dengan menyertakan pertimbangan visi hukum dan visi sosial. Akibatnya, ia tidak menjadi aplikatif dan responsif terhadap irama perkembangan masyarakat. Permasalahan yang muncul kemudian adalah "Mengapa produk-produk pemikiran hukum Islam khususnya fikih dinilai tidak apresiatif dan kondusif bagi perkembangan sosial masyarakat?". Dalam konteks inilah upaya untuk mengelaborasi dan mengeksplorasi problema di seputar penerapan pemikiran fikih menjadi hal yng menarik untuk dibahas.

\section{ANTARA FIKIH DAN SYARIAT}

Fikih menurut bahasa berarti tahu atau paham (Ali, 1997:1402). Sedangkan menurut istilah, fikih diartikan dengan berbagai macam definisi. Hasan Ahmad Khatib, sebagaimana dikutip Hasbi AshShiddieqy, mengartikan fikih sebagai kumpulan syara' yang sudah dibukukan dari berbagai nazhab yang dinukilkan dari fatwa-fatwa sahabat dan tabiin (Ash-Shiddieqy, 1987:16).

Selanjutnya Hasbi Ash-Shiddieqy sendiri menegaskan bahwa; fikih ialah segala hukum syara' yang diambil dari kitab Allah swt. dan rasul saw. dengan jalan mendalamkan paham dan penelitian atau ijtihad dan istinbât $\square$ (Ash-Shiddieqy, 1996:1). Dengan demikian, jelaslah bahwa fikih merupakan hasil olah pikir para ahli hukum Islam untuk memahami kandungan hukum syara' yang kemudian dijadikan buku pegangan mazhab tertentu. 
Dari sini jelas dipahami perbedaan fikih dengan syariat. Fikih adalah produk pemikiran manusia, sedangkan syariat ialah peraturanperaturan yang diciptakan Allah agar manusia berpegang kepadanya dalam melakukan hubungan dengan Allah, dengan sesama manusia dan dengan alam semesta (Syaltut, 1986:5).

Berdasarkan penjelasan ini maka dapat disimpulkan bahwa syariat dan fikih adalah dua konsep yang berbeda. Minimal ada empat perbedaan antara keduanya. Pertama, dilihat dari sudut subjeknya, syariat ditetapkan oleh Allah sedang fikih ditetapkan oleh manusia dalam hal ini mujtahid atau fuqaha; kedua, syariat menempati kualitas wahyu sedangkan fikih, karena di dalamnya ada intervensi ra'y (rasio), maka berkualitas ijtihadi; ketiga, karena diciptakan oleh Tuhan dan berkualitas wahyu maka syariat memiliki kebenaran absolut, sedang fikih sebagai kebenaran relatif; dan keempat, syariat bersifat universal sedangkan fikih bersifat lokal dan temporal.

Fikih merupakan responsi bagi problema hukum secara umum yang berkembang ketika diktum-diktum fikih itu ditulis. Biasanya kitab-kitab fikih meliputi seluruh aspek hukum Islam. Ia tidak memiliki ketentuan masa dan wilayah berlakunya. Keadaannya yang demikian itu menjadikan kitab-kitab fikih cenderung dianggap harus diberlakukan sepanjang masa. Akibatnya, fikih menjadi resisten (kaku) terhadap perubahan zaman.

Masalahnya adalah problema hukum yang dihadapi umat ketika kitab-kitab tersebut ditulis belum sekompleks permasalahan hukum umat pada masa sesudahnya. Demikian pula latar belakang sosiokultural umat jauh berbeda dengan kondisi umat pada masa itu. Akibatnya, sangat dilematis bila diktum-diktum yang terdapat dalam kitab fikih tersebut harus diberlakukan pada masa dan tempat berbeda.

Di Indonesia, fikih yang dipahami sebagai bagian dari penerapan syariat Islam selalu menarik untuk dikaji. Perkembangan selanjutnya dalam bidang syariat ini senantiasa memungkin lahirnya sebuah rumusan baru mengenai penerapan fikih sebagai aturan praktis yang mengandung keseluruhan hukum dan tugas keagamaan yang diturunkan oleh Pemberi hukum, yaitu Allah swt. (Zanjani, 2000:28). Dalam konteks ini, fikih dipahami sebagai ilmu yang bertautan dengan jalan menuju kehidupan akhirat dan keahlian duniawi yang 
menginteleksi kenyataan iman serta pengaruh-pengaruh yang mungkin dapat menguasai jiwa di kehidupan fana ini. Untuk itu, fikih diharapkan dapat membentuk kesalehan yang memadai untuk menjauhkan diri dari ihwal yang bersifat imanen, yang kemudian menjadi titik tumpu pergerakan menuju ihwal yang bersifat abadi dan langgeng.

\section{ELABORASI DAN EKSPLORASI PEMAHAMAN FIKIH}

Elaborasi adalah upaya mengerjakan sesuatu secara teliti dan cermat (Partanto, 1994:140). Sedangkan eksplorasi dimaknai sebagai penjelajahan atau penyelidikan sesuatu yang belum jelas atau belum dipahami (Partanto, 1994:136). Dengan demikian, yang dimaksud elaborasi dan eksplorasi pemahaman fikih adalah upaya menelusuri kembali pemahaman fikih yang saat ini dirasa kurang dinamis dan responsif terhadap perkembangan zaman, bahkan terkesan statis. Di sinilah pentingnya mencermati perkembangan fikih di mana telah diperhadapkan dengan sebuah problema utama dalam penerapannya, yaitu ketidaksesuaian antara diktum-diktum hukum yang telah dirumuskan tersebut dengan kondisi serta problema hukum dan rasa keadilan masyarakat di mana hukum tersebut diberlakukan.

Untuk penerapan produk-produk atau diktum-diktum fikih misalnya, harus dilakukan secara selektif dan melalui proses analisis yang mendalam. Ia harus diletakkan secara proporsional, yakni tidak boleh selalu dipandang sebagai hukum yang siap pakai dan secara langsung dapat diterapkan. Akan lebih bijaksana bila dipandang sebagai suatu masalah yang harus ditinjau kembali. Kita perlu merubah pemahaman masyarakat yang menempatkan fikih sebagai hukum tertinggi lalu mengkesampingkan produk pemikiran lainnya seperti putusan pengadilan dan produk perundang-undangan.

Dalam era modern ini, fikih sebagai disiplin ilmu akan berkembang sesuai dengan perkembangan masyarakat. Fikih tidak lagi sebagaimana pada zaman mujtah $\square$ idîn abad II hingga abad IV Hijriah, yang masalahnya merupakan suatu paket kumpulan hukum islami yang dipetik dari dalil-dalilnya yang tafs $\square \hat{\imath} l \hat{\imath}$, tetapi telah berkembang sesuai dengan perkembangan zaman (Djatnika,1994:28). Perkembangan ilmu fikih ini sejalan dengan munculnya masalahmasalah baru yang belum pernah ada sebelumnya yang merupakan masâil al-fiqhiyyah seperti pembahasan tentang hukum pencangkokan jantung, kornea mata, inseminasi buatan, bayi tabung dan lain-lain. 
Dengan demikian, fikih tidak mengatur tidak masalah ibadah, melainkan juga bidang-bidang kehidupan lain, seperti hubungan antara negara, hukum ketatanegaraan, administrasi pemerintahan, hukum pidana, dan peradilan. Terdorong oleh aturan hukum yang sesuai dengan perkembangan masyarakat itulah mulai dilakukan kodifikasi hadis yang menjadi landasan utama bagi tumbuhnya ilmu fikih yang mengantar pada munculnya imam-imam mazhab besar.

Itulah sebabnya Mc. Donald (1965:66) menggambarkan hukum Islam (fikih) sebagai the science of all things, human and divine (pengetahuan tentang semua hal, baik yang bersifat manusiawi maupun yang bersifat ketuhanan). Dari sini, terlihat kedudukan hukum Islam atau fikih menjadi amat penting dan menentukan pandangan hidup serta tingkah laku para pemeluk agama Islam, sehingga upaya penyesuaian dengan masalah kemoderenan terasa sangat urgen.

Akan tetapi, kedudukan fikih yang sedemikian penting dan menentukan itu ternyata sebagian besar kini merupakan proyeksi teoritis belaka, sebagai semacam fosilisasi yang hampir selesai. Dalam hal ini, hukum Islam (fikih) itu mengalami proses irelevansi secara berangsur-angsur, tetapi pasti. Masalah perdata telah banyak dipengaruhi bahkan diubah dengan hukum perdata modern. Begitu pula ketentuan-ketentuan pidananya hampir secara keseluruhan telah diganti oleh hukum pidana modern (Wahid, 1994:3). Tinggal hanya soal-soal ibadah, seperti yang banyak diajarkan oleh mazhab Syafiiyah, yang masih mendapat tempat sepenuhnya dalam kehidupan, itupun dalam kadar dan intensitas yang semakin berkurang, dan bergantung pada kemauan perseorangan para pemeluk agama Islam yang masih taat beribadah.

Rahmat Djatnika (1991:229) menerangkan bahwa hukum fikih Syafiiyah memang lebih dekat dengan kepribadian bangsa Indonesia, misalnya dalam masalah wali dalam nikah. Di Eropa, mazhab Hanafiyah lebih cocok karena di sana individualisme sangat kuat. Menurut Imam Hanafi, perkawinan lebih ditekankan kepada tanggungjawab pribadi. Oleh karena itu, jika sudah dewasa, seseorang bertanggungjawab sendiri. Orang tua tidak ikut campur tangan lagi. Itulah sebabnya, mengapa umat Islam Indonesia lebih banyak menganut fikih Syafiiyah, yaitu karena sikap kebersamaan di Indonesia lebih menonjol. 
Djatnika (1991:230) mengakui bahwa setelah zaman agak maju, pengembangan hukum fikih sudah mulai terbuka. Fikih Syafiiyah yang tidak sesuai dengan kepribadian Indonesia, secara diam-diam. mengikuti keadaan yang berkembang. Di zaman modern ini ketatnya ijâb qabûl yang diletakkan oleh Imam Syafii dalam akad jual beli hampir-hampir tidak dipakai lagi. Kalau menyerahkan sesuatu cukup dengan isyarat atau dengan kuitansi dan salah satu pihak mengatakan terima kasih, itu sudah dianggap cukup, dan kita tidak merasa tidak sah, padahal kalau kita mau berpegang kepada pendapat Imam Syafii, itu jelas tidak sah, dan itulah ijtihad.

Walaupun dalam paraktek tidak lagi berperan secara utuh dan menyeluruh, fikih Islam masih memiliki arti besar bagi kehidupan para pemeluk Islam. Pertama, fikih turut menciptakan tata nilai yang mengatur kehidupan umat Islam, minimal dengan menetapkan apa yang harus dianggap baik dan buruk, apa yang menjadi perintah, anjuran dan larangan agama; kedua, banyak putusan hukum dari fikih Islam yang telah diserap dan menjadi bagian hukum positif yang berlaku, seperti berlakunya hukum perkawinan dan kewarisan di beberapa negara termasuk di Indonesia; dan ketiga, fikih Islam menjadi bagian dari manifestasi kenegaraan Islam yang masih harus ditegakkan di masa depan, betapa jauhnya pun masa depan itu sendiri berada dalam perspektif sejarah (Djatnika, 1991: 3-5).

Karena ketiga sebab di atas, fikih Islam masih memiliki peranan cukup besar dalam kehidupan bangsa Indonesia. Peranan itu dewasa ini terasa masih bersifat statis, dalam arti masih berbentuk "pos pertahanan" untuk mempertahankan identitas keislaman dari pengaruh non-Islam, terutama yang bersifat sekuler. Sebagai pos pertahanan, fikih kadangkala hanya bersifat represif, melarang ini dan melarang itu. Dengan kata lain, fikih berkutat pada penolokan terhadap kemungkaran, kebatilan dan kemaksiatan, tetapi belum mampu menjadi penganjur kebaikan dalam arti yang luas.

Untuk memperoleh relevansi dengan perkembangan masa depan, fikih harus mampu mengembangkan watak dinamis, di antaranya dengan menjadikan dirinya penunjang perkembangan hukum nasional 
di alam reformasi ini. Watak dinamis ini hanya dapat dimiliki jika fikih meletakkan titik berat perhatiannya pada soal-soal duniawi yang menggorogoti bangsa kita dewasa ini dan memberikan pemecahan pada persoalan-persoalan hidup aktual yang dihadapi pada masa ini.

Dengan demikian, fikih dituntut untuk mengembangkan diri dalam sebuah proses yang bersifat fleksibel dan tidak hanya terikat pada gambaran dunia hayati. Dengan kata lain, fikih harus menggunakan pedekatan multi dimensional kepada kehidupan dan tidak hanya terikat pada ketentuan normatif yang telah mengendap sekian lama, bahkan hampir menjadi fosil.

Salah satu cara yang perlu dilakukan adalah menampakkan karakteristik fikih Indonesia yang tidak lagi diwarnai oleh "kepribadian Arab" (Arab-orientid), tetapi lebih menyentuh aspek yang substansial, yaitu yang sesuai dengan rasa kesadaran hukum masyarakat Indonesia yang melembaga dalam hukum adat (Wahid, 2001: 128).

Dalam kaitan ini, Hasbi Ash-Shiddieqy (1966:41-42) mengatakan:

Fikih yang berkembang dalam masyarakat kita sekarang sebagiannya adalah fikih Hijazi yaitu fikih yang terbentuk atas dasar adat istiadat yang berlaku di Hijaz, atau fikih Mishry yaitu fikih yang terbentuk atas dasar adat istiadat dan kebiasaan Mesir, atau fikih Hindi yaitu fikih yang terbentuk atas ' $u r f$ dan adat istiadat yang berlaku di India. Selama ini kita belum menunjukkan kemampuan untuk berijtihad mewujudkan fikih yang sesuai dengan kepribadian Indonesia, karena itu kadang-kadang kita paksakan fikih Hijaz, fikih Mesir atau fikih Hindi berlaku di Indonesia atas dasar taklid.

Keterasingan fikih itu antara lain juga disebabkan oleh pandangan fikih yang terlalu formalistik. Titik tolak kehidupan yang kian hari kian cenderung bersifat teologis, menjadi tidak berbanding dengan konsep legal formal yang ditawarkan oleh fikih. Teologi di sini bukan hanya berarti tauhid, tetapi merupakan pandangan hidup yang menjadi titik tolak semua kegiatan kaum muslimin. Padahal di balik itu, asumsi formalistik terhadap fikih ternyata akan dapat tersisihkan oleh hakekat fikih itu sendiri (Mahfud, 1994:41-42). 
Kecenderungan fikih yang demikian menjadikannya sebagai paradigma "kebenaran ortodoksi" di mana semua realitas ditundukkan pada kebenaran fikih. Hal ini dapat dilihat dari kenyataan bahwa hampir tidak ada sejengkal belantara kehidupan kaum muslimin yang dapat lepas dari ortodoksi fikih. Namun demikian, karena penekanan yang terlalu berlebihan pada formalisme dan kecenderungan melakukan teologisasi fikih (menundukkan realitas sosial dengan klaim teologis fikih sebagai sarananya), maka fikih seolah-olah menjauhkan diri dari realitas sosial.

Dalam hubungan ini, sudah saatnya dipikirkan upaya untuk menggeser paradigma kebenaran ortodoksi kepada paradigma pemaknaan sosial, yaitu menggunakan fikih sebagai wacana tandingan dalam kehidupan masyarakat yang tengah berlangsung. Di sini diperlukan seperangkat metodologi dalam rangka pembentukan dan penerapan hukum fikih. Upaya ini dilakukan agar fikih tetap memiliki nuansa dinamis, fleksibel dan tidak hanya berwatak "hitam putih" dalam memandang realitas.

\section{PENUTUP}

Dari uraian di atas, dapat ditarik kesimpulan bahwa dalam realitas kehidupan masyarakat Islam terdapat empat produk pemikiran hukum Islam (fikih, fatwa, putusan pengadilan dan perundangundangan) yang diberlakukan sesuai dengan kebutuhan hukum masyarakat. Namun demikian, dalam penerapannya, keempat produk pemikiran itu diperhadapkan pada problem ketidaksesuaian antara diktum-diktum hukum tersebut dengan kebutuhan dan kesadaran hukum masyarakat. Hal ini karena ketidakmampuan produk pemikiran hukum itu mengakomodir dinamika dan perubahan masyarakat. Untuk keluar dari problema tersebut, perlu dioptimalkan tradisi ijtihad sehingga peran universal syariat dapat diterjemahkan menjadi suatu konfigurasi hukum dan menyentuh rasa keadilan masyarakat dan dapat mengikuti irama perkembangan sosial kemasyarakatan di setiap tempat dan zaman.

Sebagai ilmu yang berkaitan dengan perbuatan mukallaf, perlu dielaborasi dan diekplorasi pemahaman fikih agar mudah dipahami sebagai ilmu yang bertautan dengan jalan menuju kehidupan akhirat 
dan keahlian duniawi yang menginteleksi kenyataan iman serta pengaruh-pengaruh yang mungkin dapat menguasai jiwa di kehidupan fana ini. Dengan demikian, fikih dapat membentuk kesalehan yang memadai demi menjauhkan diri dari ihwal yang bersifat imanen, yang kemudian menjadi titik tumpu pergerakan menuju ihwal yang bersifat abadi dan langgeng, yaitu bahagia di dunia dan bahagia di akhirat.

\section{DAFTAR PUSTAKA}

Ali, Atabik et. al. 1997. Kamus Kontemporer Arab-Indonesia. Cet. ke- 2. Yogyakarta: Yayasan Ali Maksum.

Amal, Taufik Adnan.1989. Islam dan Tantangan Modernitas: Studi atas Pemikiran Hukum Fazlur Rahman. Cet. ke-1. Bandung: Mizan.

Ash-Shiddieqy, Hasbi. 1966. Syariat Islam Menjawab Tantangan Zaman. Jakarta: Bulan Bintang . 1987. Pengantar Ilmu Fiqh. Cet. ke-5. Jakarta: Bulan Bintang. .1996. Hukum-hukum Fiqh Islam Cet. ke-6. Jakarta: Bulan Bintang.

Djatnika, Rahmat. 1991. Sosialisasi Hukum Islam di Indonesia dalam Kontroversi Pemikiran Islam di Indonesia. Bandung: PT. Remaja Rosdakarya. 1994. Perkembangan Ilmu Fikih di Dunia Islam. Dalam Hukum Islam di Indonesia, Perkembangan dan Pembentukan. Cet. ke-2. Bandung: Remaja Rosdakarya.

Donald, D.B. Mc. 1965. Development of Muslim Theology, Jurisprudence and Constitutional Theory. No. 10 Beirut: Khayats Oriental Reprints.

Mahfud, Sahal. 1994. Nuansa Fikih Sosial. Yogyakarta: LKIS.

Nasution, Harun. 1985. Islam Ditinjau dari Berbagai Aspeknya. Jilid II. Cet. ke-5. Jakarta: UI-Press.

Partanto, Pius A. \& M. Dahlan al-Barri. 1994. Kamus Ilmiah Populer. Surabaya: Penerbit Arkola.

Syaltut, Mahmud. 1986. Islam Aqidah dan Syari'ah. Terjemahan oleh Abdurrahman Zain. Cet. ke-1. Jakarta: Pustaka Amani.

Wahid, Abdurrahman. 1994. Menjadikan Hukum Islam sebagai Penunjang Pembangunan. dalam Hukum Islam di Indonesia, Pemikiran dan Praktek. Cet. ke-2. Bandung: Remaja Rosdakarya. 
Jurnal Hunafa Vol. 5, No.2, Agustus 2008:177-188

Wahid, Marzuki \& Rumadi. 2001. Fiqh Mazhab Negara, Kritik atas Poltik Hukum Islam di Indonesia Cet. ke-1. Yogyakarta: LKIS.

Zanjani, Ayatullah Amid. 2000. Perkembangan Fiqih Islam. Al-Huda. I (1). 